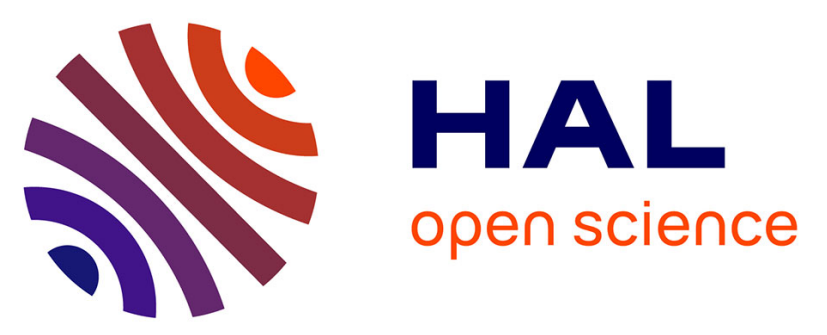

\title{
Molecular structure, magnetic properties, cyclic voltammetry of the low-spin iron(III) Bis(4-ethylaniline) complex with the para -chloro substituted meso -tetraphenylporphyrin
}

Selma Dhifaoui, Chadlia Mchiri, Pierre Quatremare, Valerie Marvaud, Anna Bujacz, Habib Nasri

\section{To cite this version:}

Selma Dhifaoui, Chadlia Mchiri, Pierre Quatremare, Valerie Marvaud, Anna Bujacz, et al.. Molecular structure, magnetic properties, cyclic voltammetry of the low-spin iron(III) Bis(4-ethylaniline) complex with the para -chloro substituted meso -tetraphenylporphyrin. Journal of Molecular Structure, 2018, 1153, pp.353-359. 10.1016/j.molstruc.2017.10.023 . hal-02403241

\section{HAL Id: hal-02403241 \\ https://hal.sorbonne-universite.fr/hal-02403241}

Submitted on 10 Dec 2019

HAL is a multi-disciplinary open access archive for the deposit and dissemination of scientific research documents, whether they are published or not. The documents may come from teaching and research institutions in France or abroad, or from public or private research centers.
L'archive ouverte pluridisciplinaire HAL, est destinée au dépôt et à la diffusion de documents scientifiques de niveau recherche, publiés ou non, émanant des établissements d'enseignement et de recherche français ou étrangers, des laboratoires publics ou privés. 


\title{
Molecular structure, magnetic properties, cyclic voltammetry of the low-spin iron(III) Bis(4-ethylaniline) complex with the para-chloro substituted meso-tetraphenylporphyrin
}

\author{
Selma Dhifaoui ${ }^{\mathrm{a}}$, Chadlia Mchiri ${ }^{\mathrm{a}}$, Pierre Quatremare ${ }^{\mathrm{b}}$, Valérie Marvaud ${ }^{\mathrm{b}}$, Anna Bujacz ${ }^{\mathrm{c}}$, \\ Habib Nasri ${ }^{a}{ }^{*}$

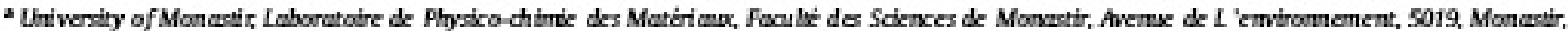 \\ Tunisin

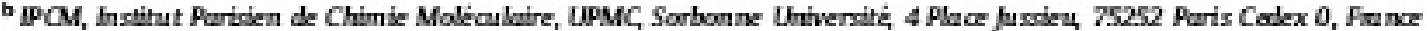

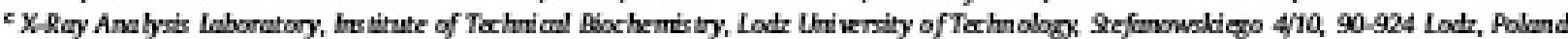

\section{A R T I C L E I N F O}

\section{Article his tory:}

Received 11 August 2017

Received in revised form

5 Octaber 2017

Accepted 6 Octaber 2017

Avribible online 9 Octbber 2017

\section{Keywords:}

Iron(III) parphyrins

$X$-ray molecular structure

UN-Visible

Magnetic data

\begin{abstract}
A B S T R A C T
In this study, the preparation of a new iron(III) hexacoordinated metalloporphyrin namely the bis(4ethylaniline)(meso-tetra(para-chlorophenyl)porphyrinato) iron(III) triflate hemi-4-ethylaniline monohydrate with the formula [ $\left.\mathrm{Fe}-(\mathrm{TClPP})\left(\mathrm{PhEtNH}_{2}\right)_{2}\right] \mathrm{SO}_{3} \mathrm{CF} 31 / 2 \mathrm{PhEtNH} \mathrm{H}_{2} \mathrm{O}$ (1) was reported. This is the first example of an iron(III) metalloporphyrin bis(primary amine) with an aryl group adjacent to the amino group. This species was characterized by elemental spectroscopic analysis including UV-visible and IR data, cyclic voltammetry, SQUID measurements and X-ray molecular structure. The mean equatorial distance between the iron(III) and the nitrogens of the porphyrin is appropriate for a low-spin (S - 1/2) iron(III) porphyrin complex. The magnetic data confirm the low-sp in state of our ferric derivative while the cyclic voltammetry indicates a shift of the half potential $\mathrm{E}_{1 / 2}[\mathrm{Fe}(111) / \mathrm{Fe}(\mathrm{II})]$ of complex (1) toward more negative value. In the crystal of (1), the [Fe'(TClPP) $\left.\left(\mathrm{PhENH}_{2}\right)_{2}\right]^{+}$ions the triflate counterions and the water molecules are involved in a number of $\mathrm{O}-\mathrm{H} \cdots \mathrm{O}, \mathrm{N}-\mathrm{H} \cdots \mathrm{O}, \mathrm{C}-\mathrm{H} \cdots \mathrm{O}$ and $\mathrm{C}-\mathrm{H} \cdots \pi$ intermolecular interactions forming a three-dimension network.
\end{abstract}

๑ 2017 Elsevier B.V. All rights reserved.

\section{Introduction}

During the late sixties and the seventies of the last century. several investigations were carried out on iron(III) metalIporphyrins with aliphatic amines leading to the autoreduction of the central metal $[1,2]$. Later on, Catro et al., reported that only sterically unhindered alkylamines are capable of reducing ferric porphyrins [3]. Several ferrous bis(primary amine) porphyrins were prepared by reduction of iron(III) porphyrinic ion complexes by primary amines with $\mathrm{C}-\mathrm{H}$ proton adjacent to the $\mathrm{NH}_{2}$ group [4]. This is the case of the [Fe' $(\mathrm{TPP})\left(\mathrm{RNH}_{2} \mathrm{k}_{2}\right]$ coordination compounds where $\mathrm{RNH}_{2}=1$-butylamine, benzylamine, and phenethylamine [4]. More recently we reported the preparation the spectroscopic and structural characterizations of two iron(II) bis(primary amine) complexes [Fe' $\left.{ }^{4}(\mathrm{TCIPP})\left(\mathrm{BzNH}_{2}\right)_{2}\right]\left(\mathrm{BzNH}_{2}=\right.$ benzylamine $[5]$ and

\footnotetext{
- Carresponding author

E-mail ad dresses: hnasri1 egmailcam, habib, mas iesmarm,tn (H. Nasri)
}

[Fe' $\left.\left.{ }^{\text {ITMPP }}\right)(\mathrm{amp}) \mathrm{2}\right]$ (TMPP = tetrakis(4-metoxyphenyl)porphyrinato and amp $=4$ (2-Aminoethyl)morpholine) by reacting iron(III) triflato starting materials [Fe' $($ Porph $)\left(\mathrm{SO}_{3}\left(\mathrm{~F}_{3}\right)\right]$ (Porph = porphyrin) with an excess of primary amines [6]. It is noteworthy that a very limited number of bis'amine) ferric metalloporphyrins is reported in the literature compared to the bis(primary amine) ferrous porphyrins. These iron(III) hexa-coordinated species only have been observed at low temperature or in high dilution $[7,8]$. Simonneaux et al. [9], reported for the first time the complete characterization of a bis(amine ester) ferric species $\left[\mathrm{Fe}^{\mathrm{II}}\right.$ (TPP) $\left.\left(\mathrm{NH}_{2} \mathrm{CHR}\right)_{2}\right] \mathrm{SO}_{3} \mathrm{CF}_{3}$ (with $\mathrm{NH}_{2} \mathrm{CHR}=$ s-leucine methyl

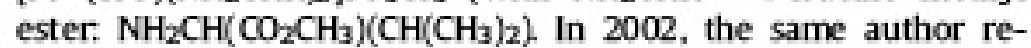
ported the molecular structure of another bis(amine ester) namely the bis( 1 -valine-methyl ester)(meso-tetraphenylporphyrinato) iron(III) ion complex [10]. In this paper, we describe the preparation, the UN-visible and IR spectroscopic characterization, the magnetic data, the cyclic voltammetry results and the molecular structure of the first example of an iron(III) bis(primary amine) with an aryl group adjacent to the $\mathrm{NH}_{2}$ group. This type of 
coordination compound is relevant to the membrane-embedded cytochrome $f$ from turnip chloroplast which has an unprecedented axial heme iron ligand: the amino terminus of the polypeptide chain [11].

\section{Experimental section}

\subsection{Materials and methods}

All reagents employed were commercially available and were used as received without further purification. The meso-tetra(parachlorophenyl)porphyrin ( $\mathrm{H}_{2}$ TCIPP) were prepared by using the Alder and Longo method [12]. All reactions and manipulations for the preparation of the ferric porphyrin derivatives were carried out under aerobic conditions. The chloro and the triflato iron(III) starting materials has been prepared using the literature reported methods $[13,14]$. Fourier-transformer IR spectra were recorded on a PerkinElmer Spectrum Two FT-IR spectrometer and UV-visible spectra were recorded with a WinASPECT PLUS (validation for SPECORD PLUS version 4.2). Cyclic voltammetry (CV) experiment was performed with a $\mathrm{CH}-660 \mathrm{~B}$ potentiostat ( $\mathrm{CH}$ Instruments) at room temperature under an argon atmosphere in a standard onecompartment, three-electrode electrochemical cell. Tetra-n-butylammonium hexafluorophosphate $\left(\mathrm{TB}_{\mathrm{APF}}\right)$ was used as the supporting electrolyte $(0.2 \mathrm{M})$ in dichloromethane previously distilled over calcium hydride under argon. An automatic Ohmic drop compensation procedure was systematically implemented before the CV data were recorded with electrolytic solution containing the studied compound at concentration of $\mathrm{ca} .10^{-3} \mathrm{M}$. CH Instruments vitreous carbon $((\emptyset=2 \mathrm{~mm})$ working electrodes were polished with $1 \mu \mathrm{m}$ diamond paste before each recording. The saturated calomel electrode SCE (TBAPF $0.2 \mathrm{M}$ in $\mathrm{CH}_{2} \mathrm{Cl}_{2}$ ) redox couple was used as the reference electrode. The potential of the ferrocene/ ferrocenium redox couple was used as an intemal reference (0.37 V/SCE experimental conditions). Temperature-dependent magnetic susceptibility measurements on polycrystalline sample of (I) was made using a Quantum Design MPMS-5SSQUID magnetometer over a temperature range of $2-300 \mathrm{~K}$ at a measuring field of $0.1 \mathrm{~T}$. Magnetization versus magnetic field measurements of (I) were carried out at $2.0 \mathrm{~K}$ in the field range $0-5 \mathrm{~T}$. The amount of material used for the measurements was $12.86 \mathrm{mg}$. Diamagnetic correction of the constituent atoms of (I) was estimated from Pascal constants [15] with value $-351.10^{-6} \mathrm{~cm}^{3} \mathrm{~mol}^{-1}$.

\subsection{Preparation of complex (I)}

\subsubsection{Synthesis of [ $\left.\mathrm{Fe}^{\mathrm{II}}(\mathrm{TCIPPP})\left(\mathrm{PhEt}_{\mathrm{NH}}\right)_{2}\right] \mathrm{SO}_{3} \mathrm{CF}_{3} 1 / 2\left(\mathrm{PhEtNH}_{2}\right)$ $\mathrm{H}_{2} \mathrm{O}$ (I)}

[Fe' (TCPP) $\left.\left(\mathrm{SO}_{3} \mathrm{CF}_{3}\right)\right](50 \mathrm{mg}, 0.05 \mathrm{mmol})$ and 4-ethylaniline (100 mg, $0.60 \mathrm{mmol}$ ) were dissolved in dichloromethane $(10 \mathrm{~mL})$. The mixture was stirred at room temperature for $4 \mathrm{~h}$. The solution was filtered, and crystals of the complex were prepared by slow diffusion of $\mathrm{n}$-hexane into the dichloromethane solution. Yield $10 \mathrm{mg}, 0.01 \mathrm{mmol}(20 \%) . \mathrm{C}_{65} \mathrm{H}_{53.5} \mathrm{Cl}_{4} \mathrm{~F}_{3} \mathrm{FeN}_{65} \mathrm{O}_{4} \mathrm{~S}$ (1276.35); Calcd. C 61.16; H 4.22; N 7.13; Found: C 61.25; H 4.31; N 7.26; UV-visible $\left[\mathrm{CH}_{2} \mathrm{Cb}\right]: \lambda_{\max }\left(\mathrm{c}_{10^{-3}}\right): 416(265), 555$ (18) nm.

\section{3. $X$-ray structure determination}

The data collection for (I) was performed with a Bruker APEXII $C C D$ Gemini ultra-diffractometer equipped with $\mathrm{Cu}-K \alpha$ radiation source $(\lambda=1.54184 \lambda)$. The intensity data was collected by the narrow frame method and the measurements of the data were done at $100 \mathrm{~K}$. The reflections were scaled and corrected for absorption effects by using the Crys Alis [16]. The structure was solved

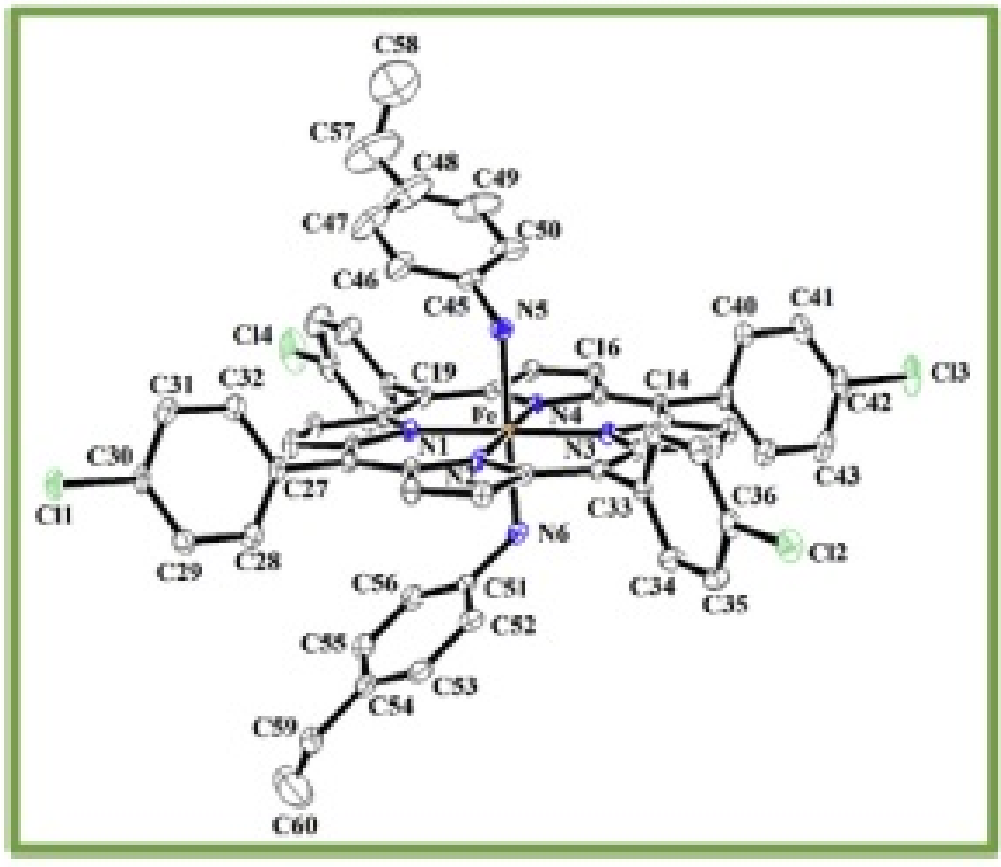

Fiz 1. ORIEP diagran of the [Fe" (TCIPPYPhEtNH $\left.)_{2}\right]^{+}$ion complex (1). Ellipsoids are drawn at $\Delta 0 \%$ and the hydroger atoms are omitted for clarity.

by direct methods by using SIR-2004 [17] and refined by full-matrix least-squares techniques on $F^{2}$ by using the SHELXL-2014 program [18]. The crystallographic data and structural refinement details of complex (I) are shown in Table $\mathbf{1}$

\section{Results and discussion}

3.1. Structural properties of $\left[\mathrm{Fe}^{\prime \prime \prime}(\mathrm{TClPPP})\left(\mathrm{PhEtNH}_{2} \mathrm{k}_{2}\right] \mathrm{SO}_{3} \mathrm{CF}_{3} 1 /\right.$

2 (PhEtNH2) $* \mathrm{H}_{2} \mathrm{O}(\mathrm{I})$

Complex (I) crystallizes in the monoclinic crystal system ( $P 2 \mathrm{~V} / n$

Table 1

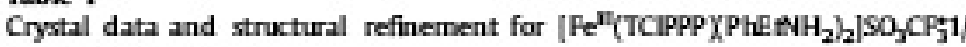
$2\left(\mathrm{PhENH}_{2}\right) * \mathrm{H}_{2} \mathrm{O}(\mathrm{I})$.

\begin{tabular}{|c|c|}
\hline Formula & $\mathrm{C}_{6} \mathrm{H}_{52} \mathrm{C}_{4} \mathrm{~F}_{3} \mathrm{FeN}_{63} \mathrm{O}_{4} \mathrm{~S}$ \\
\hline Dealc. $/ g \mathrm{~cm}^{-3}$ & $1 A 46$ \\
\hline$\mu\left(\mathrm{mm}^{-1}\right)$ & 0.481 \\
\hline Farmula Weight & 1276.35 \\
\hline Calour & brown \\
\hline Shape & block \\
\hline Size/mm $\mathrm{mm}^{3}$ & $0.40 \times 0.22 \times 0.12$ \\
\hline $\mathrm{T}(\mathrm{K})$ & $10 \alpha 2) K$ \\
\hline Crystal System & monodirüc \\
\hline Space Croup & $\mathrm{P}_{2} / \mathrm{n}$ \\
\hline$a(A)$ & $16.4360(3)$ \\
\hline $\mathbf{b}(\mathrm{A})$ & $15.4960(3)$ \\
\hline$c(A)$ & $231719(4)$ \\
\hline$a()$ & 90 \\
\hline $\left.\boldsymbol{R}^{*}\right)$ & $965132)$ \\
\hline $8(6)$ & 90 \\
\hline$W\left(A^{3}\right)$ & $5893.61(19)$ \\
\hline 2 & 4 \\
\hline $\operatorname{P000}\left(A^{3}\right)$ & 2632 \\
\hline radiation-type & CuKa \\
\hline $\operatorname{\theta min}\left({ }^{\circ}\right)$ & 3.438 \\
\hline$\left.\theta \max ()^{\circ}\right)$ & 75096 \\
\hline Reflections measured & 45088 \\
\hline Independent reflections & 8365 \\
\hline Parmeters & 853 \\
\hline $\operatorname{Coaf}(S)$ & 1.028 \\
\hline$R_{1}$ (all data) & 0.0411 \\
\hline$w R_{2}$ (all data) & 0.1053 \\
\hline$C O D C$ & 1563523 \\
\hline
\end{tabular}

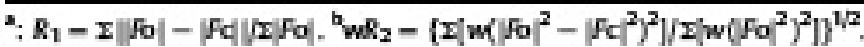


Table 2

Selected bond lengths and migles for [ $\left.\left.\mathrm{Fe}^{\mathrm{II}}\left(\mathrm{TCPPP} \mathrm{PPhEtNH}_{2}\right)_{2}\right] \mathrm{SO}_{3} \mathrm{Cr} 1 / 2 \mathrm{PhEtNH}_{2}\right)$ ${ }^{\circ} \mathrm{H}_{2} \mathrm{O}(\mathrm{I})$.

\begin{tabular}{|c|c|c|c|}
\hline Distances (A) & & Angles $\left({ }^{\circ}\right)$ & \\
\hline \multicolumn{4}{|c|}{ Iron(III) coordination polyhedron } \\
\hline $\mathrm{Fe}-\mathrm{N} 1$ & $19814(16)$ & N1-PeN2 & $8984(6)$ \\
\hline $\mathrm{Fe}-\mathrm{N} 2$ & $1.9952(16)$ & $\mathrm{N} 1-\mathrm{Pe}-\mathrm{N} 4$ & $90.40(6$ \\
\hline $\mathrm{Fe}-\mathrm{N} / 3$ & $1.9926(15)$ & $\mathrm{N} 1-\mathrm{Pe}-\mathrm{N} 3$ & $179276)$ \\
\hline $\mathrm{Fe}-\mathrm{N} 4$ & $1.9968(16)$ & NE-PeN6 & $177.82(6)$ \\
\hline Fe-NS & $20435(16)$ & & \\
\hline Fen N6 & $20465(16)$ & & \\
\hline \multicolumn{4}{|c|}{ 4-ethylaniline axial ligand } \\
\hline C45-N5 & $1.448(2)$ & C51-NG-Fe1 & 12090 \\
\hline C51-N6 & $1.4 \triangleq \alpha(2)$ & CSG-CS1-C52 & $11999(19)$ \\
\hline C51-C56 & $1,387(3)$ & & \\
\hline $\mathrm{CS} 1-\mathrm{CS} 6$ & $1.387(3)$ & & \\
\hline
\end{tabular}

space group). The iron(III) cation is coordinated by four pyrrole $\mathrm{N}$ atoms of the porphyrin macrocycle and the nitrogen atoms of two trans 4-ethylaniline axial ligands in an octahedral geometry. The asymmetric unit of our iron(III) derivative is made by one [Fe $\left.{ }^{-1}(\mathrm{TClPPP})\left(\mathrm{PhEtNH}_{2}\right)_{2}\right]^{+}$ion complex and $\mathrm{SO}_{3} \mathrm{CF}_{3}$ counterion, half non-coordinated $\mathrm{PhEt} \mathrm{NH}_{2}$ molecule and one water molecule. An ORTEP drawing of the $\left[\mathrm{Fe}^{\mathrm{II}} \text { (TClPP) }\left(\mathrm{PhEtNH}_{2}\right)_{2}\right]^{+}$ion complex is illustrated by Fig. 1. Selected bond distances and angles for this compound are listed in Table 2 .

The distance between the central metal and the nitrogen atom of the $\mathrm{PhEtNH}_{2}$ axial ligand is 2.045(16) A which is close to those of the related bis(primary amine) iron(II) porphyrins type [Fe(TPP) $\left.\left(\mathrm{RNH}_{2}\right)_{2}\right][4]$. It has been shown that the average equatorial distance between the iron(III) and the nitrogen atoms of the porphyrin ring $(\mathrm{Fe}-\mathrm{Np})$ is related to the spin-state of the ferric metalloporphyrin [19]. Thereby, for high-spin (HS) $(S=5 / 2)$ complexes, the $\mathrm{Fe}-\mathrm{Np}$ bond length values are the longest (Table 3), e.g. for the $\left[\mathrm{Fe}(\mathrm{TPP})\left(\mathrm{H}_{2} \mathrm{O}\right)_{2}\right]^{+}$ion complex, $\mathrm{Fe}-\mathrm{Np}$ amounts to $2.045 \AA$ [20]. For iron(III) bw-spin (LS) $(S=1 / 2)$ metalloporphyrins, the $\mathrm{Fe}-\mathrm{Np}$ bond values are smaller than those of the HS species and range between $1.998 \AA$ and $1.952 \AA$. For (I), the $\mathrm{Fe}-\mathrm{Np}$ distance of $1.9915(16) \AA$ is an indication that this species is an iron(III) low-spin $(S=1 / 2)$ porphyrin complex.

The porphyrin macrocycle of (I) presents a nearly planar confirmation with maximum and minimum deviation from the $\mathrm{C}_{20} \mathrm{~N}_{4}$ mean plan of 0.15 (17) $\AA$ and $-0.12(24) \AA$ for atom $\mathrm{Cl}$ and $\mathrm{C17}$ respectively while the iron(III) central metal is practically in the central of this mean plane (Fig. SI-2). For the related 4cyanopyridine with the meso-tetraphenylporphyrin ion complex $\left.\left[\mathrm{Fe}^{\mathrm{II}} \text { (TPP)(4-CNpy }\right)_{2}\right]^{+}[21]$, the porphyrin core is very distorted due to the interaction between the ortho hydrogens of the 4cyanopyridine axial ligands and the nitrogen of the porphyrin macrocycle with a distance of $-2.52 \mathrm{~A}$. Therefore, these ortho $\mathrm{H}$ of the 4-CNpy axial ligand point away from the pyrrole nitrogens (Fig. 2). For our bis(4-ethylaniline)-iron(III) derivative, due to the presence of the amino group of the $\mathrm{PhEtNH}_{2}$ axial ligand, the interaction between the ortho $\mathrm{H}$ atoms of the phenyl group of the axial ligand and the nitrogen of the pyrroles is weaker compared to the bis(4-CNpy) iron(III) species with a distance between the closest porphyrin nitrogen and the ortho $\mathrm{H}$ of the primary amine axial ligand of about $3.00 \mathrm{~A}$. Consequently, the ortho protons of the axial ligands nearly eclipse the closest $\mathrm{Fe}-\mathrm{Np}$ vectors and $\mathrm{ke}$ porphyrin core of (I) is rather planar.

A [ $\mathrm{Fe}^{\mathrm{Il}}$ (TCPPP)(PhEtNH $\left.\mathrm{T}_{2}\right]^{+}$ion complex is linked to a $\mathrm{SO}_{3} \mathrm{CF}_{3}$ counterion and a water molecule via $\mathrm{N}-\mathrm{H} \cdots \mathrm{O}$ hydrogen bonds with

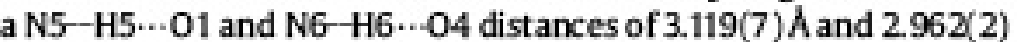

Table 3

Selectad structural features of several six-coardintes iron(III) and iron(II) metalloparplryr ins.

\begin{tabular}{|c|c|c|c|c|}
\hline Complex & $\mathrm{Fe}-\mathrm{N}^{2}(\mathrm{~A})$ & $\mathrm{Pe}-\operatorname{lax}^{h}(A)$ & St-tt Spin & Ref \\
\hline \multicolumn{5}{|l|}{ Iron(III) metalloporphyrins } \\
\hline$\left[\mathrm{Fe}(\mathrm{TPP} / \mathrm{PF})_{2}\right]^{+c}$ & 2.064 & 1.966 & $5 / 2$ & {$[22]$} \\
\hline Fe(OEPXDMSO b $]^{+4=}$ & 2.037 & 2083 & $5 / 2$ & {$[23]$} \\
\hline$\left[\mathrm{Fe}\left(\mathrm{TPP} \mathrm{CH}_{2} \mathrm{H}_{2} \mathrm{O}_{2}\right]^{+}\right.$ & 2.045 & 2095 & $5 / 2$ & [19] \\
\hline$\left[\mathrm{Fe}(\mathrm{TPP})(4-\mathrm{MeH} / \mathrm{m})_{2}\right]^{+t}$ & 1998 & $1.928 / 1.958$ & $1 / 2$ & {$[24]$} \\
\hline$\left[\mathrm{Fe}(\mathrm{TPP} / \mathrm{p} y)_{2}\right]^{+}$ & 1982 & $2005 / 2001$ & $1 / 2$ & [25] \\
\hline $\left.\mathrm{Fe}\left(\mathrm{TPP} \mathrm{X}_{4}-\mathrm{CNPy}\right)_{2}\right]^{+8}$ & $1952(7)$ & $2002(8)$ & $1 / 2$ & [26] \\
\hline$\left[\mathrm{Fe}\left(\mathrm{OEP} \mathrm{X}(3-\mathrm{OP} y)_{2}\right]^{\text {th }}\right.$ & $1994(2)$ & $2031(2)$ & $1 / 2$ & {$[27]$} \\
\hline$\left[\mathrm{Fe}\left(\mathrm{TMP} \mathrm{X}_{1} 1 \text { - Melm }\right)_{2}\right]^{+\mathrm{W}}$ & $1988(20)$ & $1.973(6) 1.957(6)$ & $1 / 2$ & [21] \\
\hline$\left[\mathrm{Fe}\left(\mathrm{TMPX}_{4}-\mathrm{NMe}_{2} \mathrm{Py}\right)_{2}\right]^{+\mathrm{R}}$ & $1964(4)$ & $1.989(4)$ & $1 / 2$ & [21] \\
\hline$\left[\mathrm{Fe}\left(\mathrm{TPP}_{2} \mathrm{C}_{6} \mathrm{H}_{13} \mathrm{NO}_{2}\right)_{2}\right]^{+1}$ & $1997(2)$ & $20242)$ & $1 / 2$ & {$[10]$} \\
\hline$\left[\mathrm{Fe}\left(\mathrm{TClPP} P \mathrm{Xh}\left(\mathrm{PtNH}_{2} \mathrm{~h}_{2}\right]^{+}\right.\right.$ & $19915(14)$ & $2045(16)$ & $1 / 2$ & this wark \\
\hline \multicolumn{5}{|l|}{ Iran(II) metal loparphry ins } \\
\hline (Fe(TMPP) (amp) $]^{m, n}$ & $1988(2)$ & $20372)$ & 0 & {$[7]$} \\
\hline$\left[\mathrm{Fe}\left(\mathrm{TPP} X \mathrm{C} 1-\mathrm{BuNH}_{2}\right]_{2}\right]^{a}$ & $1989(1)$ & $2039(3)$ & 0 & [4] \\
\hline${ }^{\mathrm{Fe}}\left(\mathrm{TPP} \mathrm{XBz}_{\mathrm{z}} \mathrm{NH}_{2} \mathrm{~h}_{2} \mathrm{P}\right.$ & $1992(4)$ & $2043(3)$ & 0 & [4] \\
\hline [Fe(TPP) $\left.\left(\mathrm{PhCH}_{2} \mathrm{CH}_{2} \mathrm{NH}_{2}\right)_{2}\right]^{q}$ & $1989(4)$ & $202 \Omega(2)$ & 0 & [4] \\
\hline
\end{tabular}

- $\mathrm{Fe}-\mathrm{Np}$ - average equator ial distance between the iron and the ritrogen atoms of the porphyrin ring.

b $\mathrm{Fe}-\mathrm{Lax}$ - iron-axial ligand distance.

c TPP - mes-tetraphenylporphyrinats.

d OEP - octaetlyl por phyrinata.

- DMSO - dimethylsulfoxide.

4-MeHlm - 4-methylimidazale.

8 4-CNpy - 4-cyanopyridine.

h 3-Clpy - 3-chlor opy ridine.

I TMP - meso-tetramesi tyl porlny inata.

1 1-MeHlm - 1-methylimidazale.

4 4-NMerpy - 4-(dimethylamino)pyridine,

${ }^{1} \mathrm{C}_{6} \mathrm{H}_{13} \mathrm{NO}_{2}$ - Lvaline- $\mathrm{N}$ methyl exter.

m Tetrakis(4-metoryphenyl) porphyrinatol.

n amp - 4(2-aminoethyl)mar pholine.

a 1-BuNH -1 -butylamine.

? $\mathrm{B}_{2} \mathrm{NH}_{2}-$ benzylamine.

q $\mathrm{PhCH}_{2} \mathrm{CH}_{2} \mathrm{NH}_{2}$ - phenethylamine. 


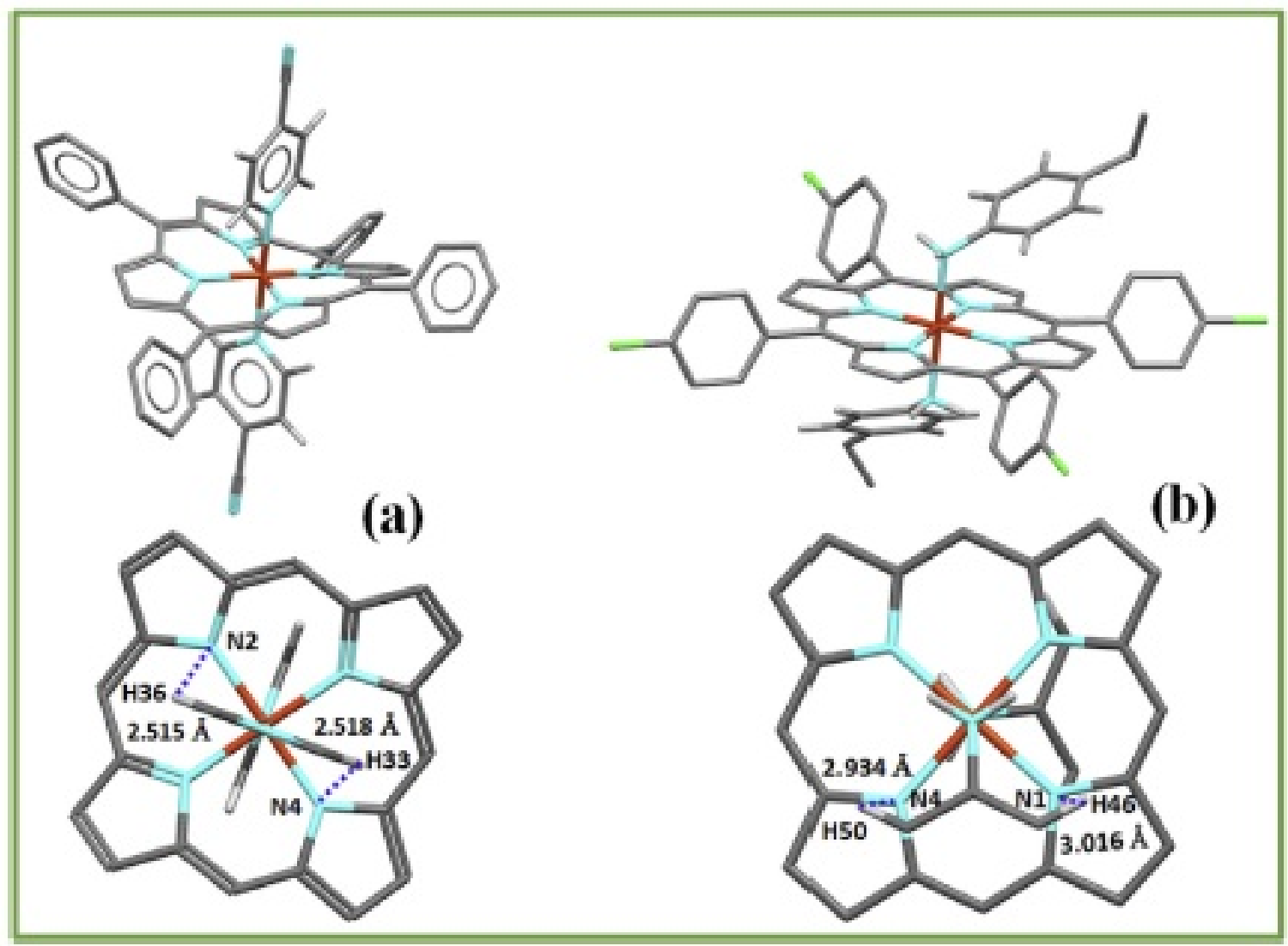

Fiz 2. Drawing showing the deformation of the porplyrin macrocycle (top view) and the interactions between the nitrogen attoms of the porphyrin ring and the Hortho of the axial

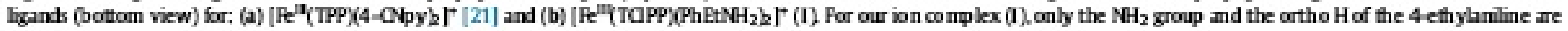
shown

A respectively. The counterion and the nearby water molecule are linked together via the oxygen 04 of this water molecule and the axygen atom $\mathrm{O} 2$ of the $\mathrm{SO}_{3} \mathrm{CF}_{3}^{-}$counterion $[04-\mathrm{H} 4 \cdots 02$ distance is $2.897(5) \mathrm{A}]$ (Fig. 2. Fig. SI-3 and Tables SI-1). By the other hand, the carbon C30 of a phenyl ring of a TCIPP moiety and the oxygen 03 of a neighboring $\mathrm{SO}_{3} \mathrm{CF}_{3}$ counterion are weakly bonded via a $\mathrm{C}-\mathrm{H} \cdots \mathrm{O}$ non-conventional $\mathrm{H}$ bond with a $\mathrm{C} 31-\mathrm{H} 31 \ldots \mathrm{O} 3$ distance of 3.475(7) A (Fig. 3 and Fig. SI-3). The three-dimensional

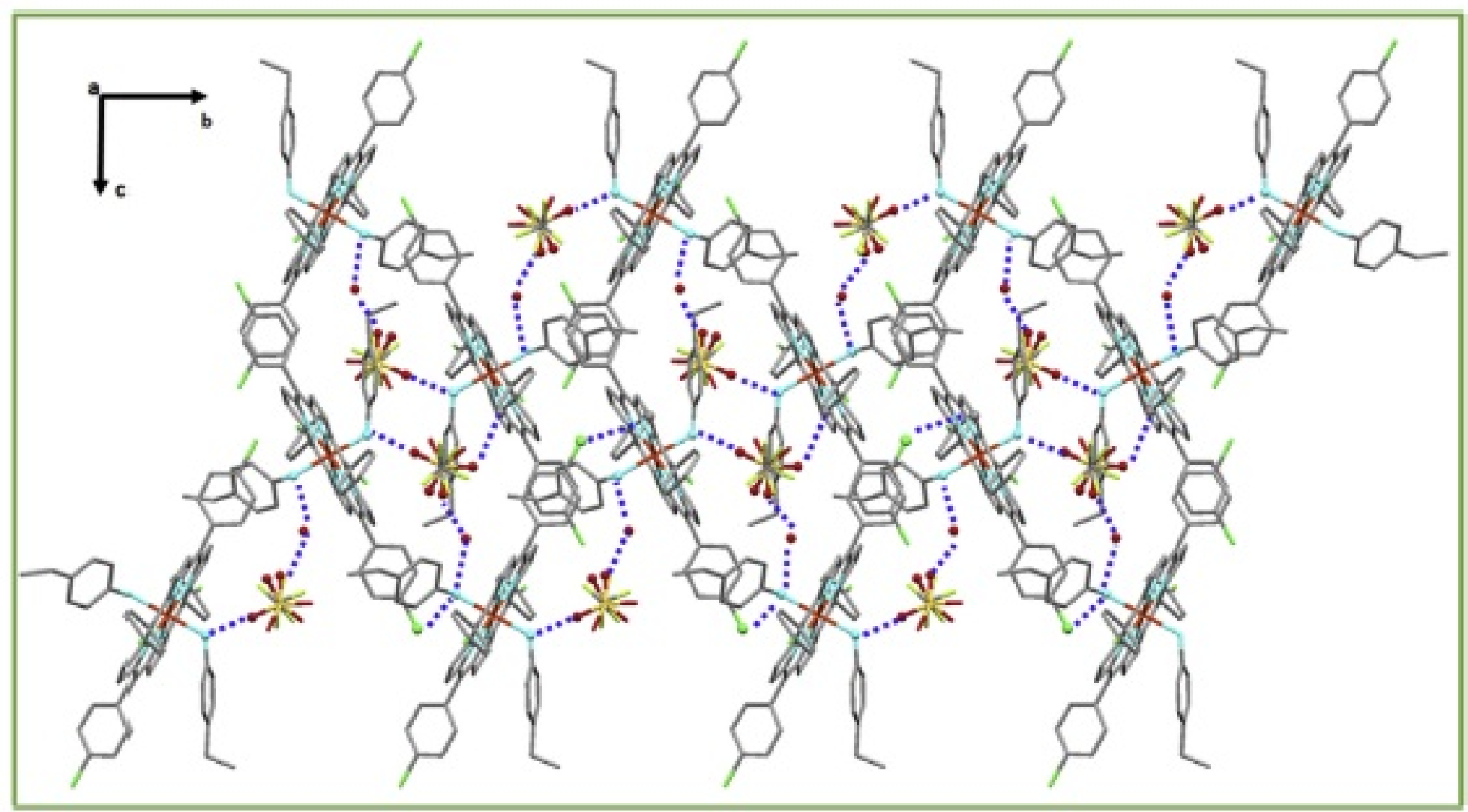

Fig. 3. A partial view of the crystal packing of the title compound plotted in projection along the [100] direction. 


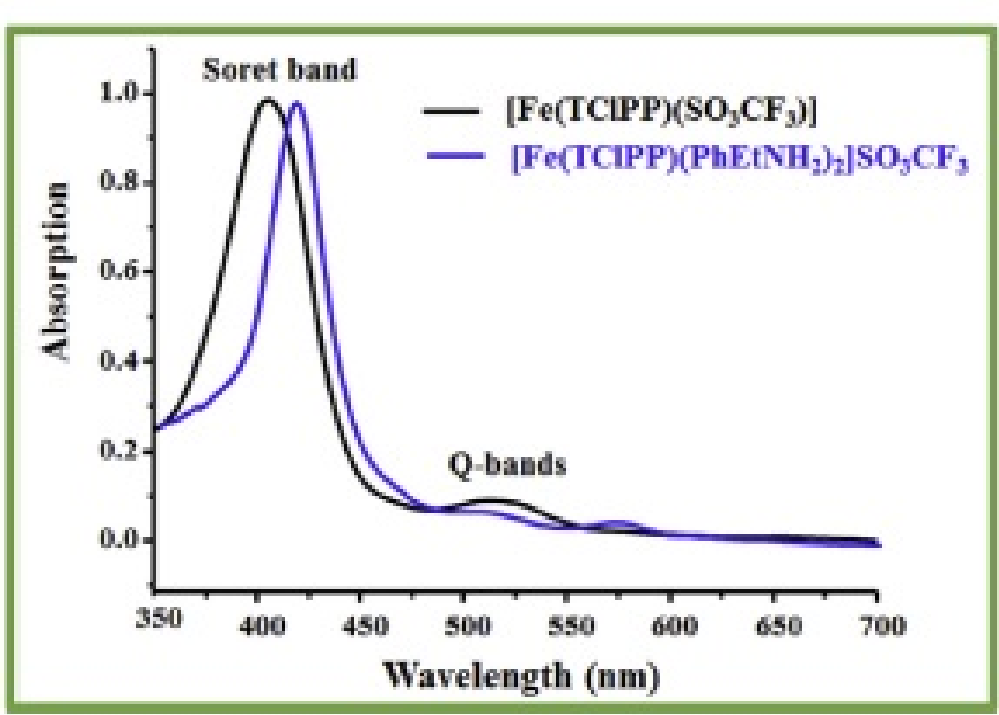

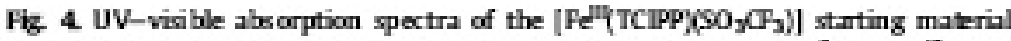
and complex (I) in $\mathrm{CH}_{2} \mathrm{Cl}_{2}$ solution at concentrations of $208 \mathbf{1}^{-6}$ for $\left[\mathrm{Fe}^{-1}(\mathrm{TCP}\right.$ $\left.P \mathrm{SO}_{3} \mathrm{CF}_{3}\right]$ and $1.7510^{-6}$ for (I).

supramolecular structure of $(\mathbf{I})$ is further stabilized by the $\mathrm{C}-\mathrm{H}$... $\mathrm{Cg}$ intermolecular interactions between the $\mathrm{Cl} 1$ carbon of a pyrrole ring of one TCIPP porphyrinato and the centroid $\mathrm{Cg} 14$ of the phenyl group of the 4-ethylaniline of an adjacent [Fe"I(TCIPPP) $\left.\left(\mathrm{PhEtNH}_{2}\right)_{2}\right]^{+}$ion complex (Fig. Sl-3).

\subsection{UV-visible and $\mathbb{R}$}

Fig. 4 represents the UV-visible spectra of (I) and the [Fe ${ }^{\mathrm{II}}$ (TClPP) $\left.\left(\mathrm{SO}_{3} \mathrm{CF}_{3}\right)\right]$ starting material. The $\lambda_{\max }$ value of the Soret band of our iron(III)-bis(4-ethylaniline) which is $416 \mathrm{~nm}$ is redshifted compared to iron(III)-triflato starting material but very close to those of the iron(III)-bis(amine primary) meso-tetraphemylporphyrins [ $\left.\mathrm{Fe}{ }^{\mathrm{I}}(\mathrm{TPP})\left(\mathrm{NH}_{2} \mathrm{CHR}\right)_{2}\right]^{+}$related species [7] and other bis(substituted pyridine) and bis(substituted imidazole) iron(III) metalloporphyrins (Table 4). Thus, the UV-visible data of (I) indicate that in dichloromethane solution our $\mathrm{Fe}$ (III) derivative is hexacoordinated type $\left[\mathrm{Fe}^{\mathrm{II}}(\mathrm{Porph})\left(\mathrm{L}_{2}\right]^{+}\right.$where Porph is a mesoporphyrin and $\mathrm{L}$ is a neutral $\mathrm{N}$-donor axial ligand.

The IR spectrum of our iron(III) derivative (Fig. SI-1) exhibits strong absorption bands at 3122 and $1613 \mathrm{~cm}^{-1}$, attributed to the $\mathrm{N}$ $\mathrm{H}$ and the $\mathrm{C}-\mathrm{H}$ stretching frequency respectively of the 4 ethylaniline axial ligand. The presence of the triflate counterion is confirmed by three absorption bands at 1256, 1153 and $626 \mathrm{~cm}^{-1}$ [14]. Thereby, the IR results confirm the presence of the 4 ethylaniline axial ligand and the $\mathrm{SO}_{3} \mathrm{CF}_{3}^{-}$counterion.

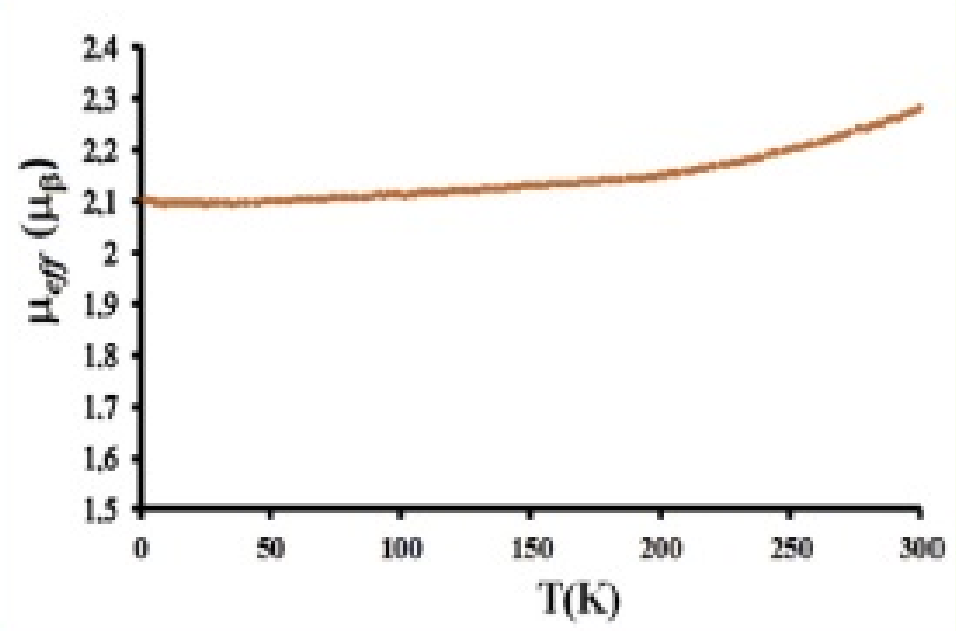

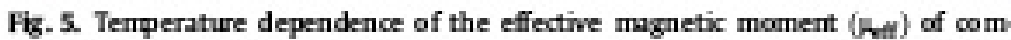
plex (1).

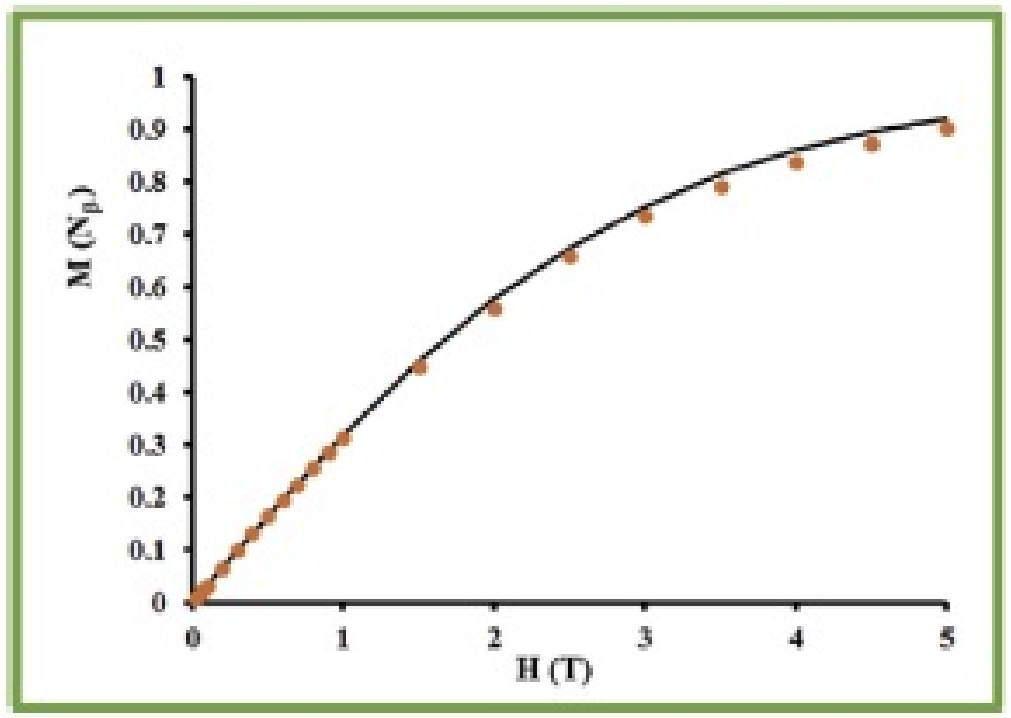

Fig.6. Magnetimation versus the applied magnefic fiedd at $20 \mathrm{~K}$. (o) experimental data of (I). The black line is the Brillouin function with $\mathrm{g}-2$

\subsection{Magnetic data}

Magnetic properties were investigated for complex (I) via SQUID magnetometry over the temperature range $2-300 \mathrm{~K}$. Plots of the effective magnetic moment $\left(\mu_{\text {eff }}\right)$ versus the temperature of the polycrystalline samples are illustrated in Fig. 5. The Heff values at $2.0 \mathrm{~K}$ and $300 \mathrm{~K}$ are $2.10 \mu_{\beta}$ and $2.30 \mu_{\beta}$ respectively which are

Table 4

UN-visible data of our synthetic species and selected iron(III) metalloporphyr irs.

\begin{tabular}{|c|c|c|c|}
\hline Compound & Soret band $\lambda_{\max }[\mathrm{rm}]\left(\& 10^{-3}\left(\mathrm{~L} \mathrm{~mol}^{-1} \mathrm{~cm}^{-1} \mathrm{D}\right.\right.$ & $Q$ bends $\lambda_{\max }[\mathrm{nm}]\left(t 10^{-3}\left(\mathrm{~L} \mathrm{~mol}^{-1} \mathrm{~cm}^{-1} \mathrm{D}\right.\right.$ & Ref \\
\hline $\mathrm{H}_{2} \mathrm{TCPP}$ & $420(350)$ & $515(23), 548(11), 593(7), 646(4)$ & this wark \\
\hline$\left[\mathrm{Fe}(\mathrm{TCIPP})\left(\mathrm{SO}_{3} \mathrm{CF}_{3}\right)\right]$ & $408(108)$ & $515(11)$ & this wark \\
\hline [Fe(TCIPP)PhE $\left.\left.\mathrm{NH}_{2}\right)_{2}\right]^{+\infty}(\mathrm{I})$ & $416(265)$ & $555(18)$ & this wark \\
\hline $\mathrm{Fe}^{\mathrm{ill}}\left(\mathrm{TPPX}_{\mathrm{X}} \mathrm{NH}_{2} \mathrm{CHR}_{2}\right]^{+\mathrm{b}_{f}}$ & 415 & 541,571 & {$[7]$} \\
\hline $\left.\mathrm{Fe}^{\mathrm{NI}}\left(\mathrm{TMP}_{\mathrm{X}} \text { 4-NMePy}\right)_{2}\right]^{+\mathrm{d} / e}$ & 415 & 554588 & [28] \\
\hline$\left.[\text { Fe(TMPX2-Melm) }]_{2}\right]^{+t}$ & 417 & 560,582 & {$[28]$} \\
\hline$\left.\left[\mathrm{Fe}(\mathrm{TMP})_{1} 1-\mathrm{Melm}\right)_{2}\right]^{+8}$ & 416 & 550,580 & {$[28]$} \\
\hline
\end{tabular}

a $\mathrm{PhEtNH}$ - 4ethylaniline.

b TPP - meso-traphenylparphyrinab.

c $\mathrm{NH}_{2} \mathrm{CHR}$ - Lleucine methyl ester.

d TMP - meso-tetramesi tyl porlyr inata.

- 4-NMePy - 4-(dimethylamino) pyridine.

' 2-MeHlm - 2-methylimidnzole.

8 1-MeHlm - 2-methylimidnzale. 


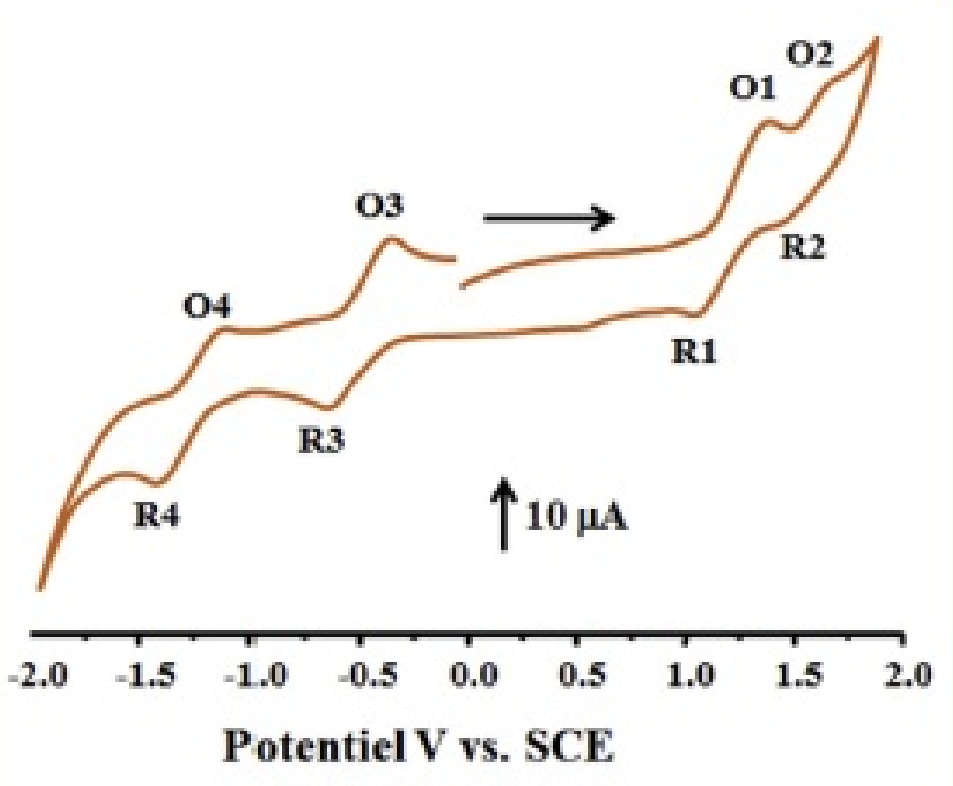

Fiz 7. Cyclic voltammogram of (I). The solvent is $\mathrm{CH}_{2} \mathrm{Cl}_{2}$ and the concentration is $\mathrm{Ca}$ $10^{-3} \mathrm{M}$ in $0.2 \mathrm{M}$ TRAPF $60 \mathrm{mV} / \mathrm{s}$, vitreous carbon wodking dectrode $(\Theta-2 \mathrm{~mm}$ ).

appropriate for low-spin ( $S=1 / 2)$ iron(III) compounds with $g=2$. Increasing the temperature results in a gradual increase in the magnetic moment. This increase can arise from cooperative interactions between the $\left[\mathrm{Fe}^{\mathrm{II}}(\mathrm{TCPP})\left(\mathrm{PhEt} \mathrm{NH}_{2}\right)_{2}\right]^{+}$ion complexes [29]. The field dependence of the magnetization $M=f(H)$ at $2 \mathrm{~K}$ is given in Fig. 6. The experimental magnetization (M) values are compatible with the theoretical ones calculated from the Brillouin function for $S=1 / 2$ ground state and $g=2$ for (I).

\subsection{Cycic voltammetry}

The electrochemical behavior of (I) was studied by cyclic voltammetry (CV) with tetra-n-butylammonium hexafluorophosphate ( $\mathrm{TBAPF}_{6}$ ) as the supporting electrolyte $(0.2 \mathrm{M})$ in the non-coordinating solvent dichloromethane under an argon atmosphere. The $\mathrm{CV}$ of the species are illustrated in Fig. 7 and the values of the half potential waves of our derivative along with other related iron(III) metalloporphyrins are given in Table 5. The anodic part of the cyclic voltammogram of (I) includes one electron reversible oxidation wave of the iron [Fe(III)/Fe(IV)] (R1/O1) with $E_{1 / 2}$ value of $1.11 \mathrm{~V}$ and a second one-electron irreversible oxidation wave $(02 / R 2)$ attributed to the oxidation of the porphyrin ring where the $\mathrm{E}_{1 / 2}$ value is $-1.60 \mathrm{~V}$. The cathodic part of the $\mathrm{CV}$ exhibits one-electron reversible reduction wave of the $\mathrm{Fe}$ (III) to $\mathrm{Fe}$ (II) (R3) 03) with a half-potential value of $-0.38 \mathrm{~V}$ while the one-electron reversible reduction ( $\mathrm{R} 4 / \mathrm{O} 4)$ wave at $\mathrm{E}_{1 / 2} \sim-1.23 \mathrm{~V}$ could be attributed to the $\mathrm{Fe}(\mathrm{II}) / \mathrm{Fe}$ (I) reduction. In the literature, several imvestigations by cyclic voltammetry on the $\mathrm{Fe}$ (III)/ $\mathrm{Fe}$ (III) reduction of ferric metalloporphyrins have been reported $[30,31]$ and attempts have been made to correlate the changes of the $\mathrm{E}_{1 / 2}$ [ $\mathrm{Fe}$ (III)/ $\mathrm{Fe}(\mathrm{II})]$ value with metal spin state, axial-ligand coordination, basicity of the porphyrin ring, counterion and the deformation of the porphyrin core. For low-spin $\mathrm{Fe}$ (III) porphyrin species type $\left[\mathrm{Fe}^{\mathrm{II}}(\text { Porph })(\mathrm{L})_{2}\right]^{+}$. (Porph $=$meso or $\beta$-pyrrole substituted porphyrin ), where $\mathrm{L}$ is a $\mathrm{N}$-donor neutral planar axial ligand, it has been noticed that the shift of the $\mathrm{E}_{1 / 2}[\mathrm{Fe}$ (III)/ $\mathrm{Fe}$ (II)] toward more positive values is related to distortion of the porphyrin core. Thus, in the case of $\left[\mathrm{Fe}^{\mathrm{II}}\{(\mathrm{TPP})(2-6 \mathrm{~F})\}(\mathrm{py})_{2}\right]^{+}$where $\{(\mathrm{TPP})(2-6 \mathrm{~F})\}$ is the meso-tetrakis(2,6-difluorophenyl)porphyrinato, the half-potential of the $\mathrm{Fe}$ (III)/ $\mathrm{Fe}$ (II) reduction is $0.35 \mathrm{~V}$ [32]. In contrast, the $\left.\left[\mathrm{Fe}^{\text {III }}(\mathrm{OEP})(1-\mathrm{NMelm})_{2}\right)\right]^{+}$ion complex $(\mathrm{OEP}=$ octaethylporphyrin and 1-NMelm $=1$-methylimidazole), the $\mathrm{E}_{1 / 2}[\mathrm{Fe}(\mathrm{III}) / \mathrm{Fe}$ (II)] value is $-0.39 \mathrm{~V}$ for which the porphyrin macrocycle of the OEP porphyrinate is practically planar [33]. For our iron(III)-TCPP bis ( 4 ethylaniline) complex, the $\mathrm{E}_{1 / 2}$ [Fe(III)/Fe(II)] value is $-0.38 \mathrm{~V}$. This is compatible with a ferric hexa-coordinated metalloporphyrin with planar porphyrin core which is the case of (I) (see crystallographic section).

Tables

Electrochernical data for (I) and a selection of related iron(III) metalloporplyrins in $\mathrm{CH}_{2} \mathrm{Cl}_{2}$ (exceptions are indicatad)

\begin{tabular}{|c|c|c|c|c|c|}
\hline \multirow[t]{3}{*}{ Complex } & \multirow[t]{3}{*}{ Ring oxidation } & \multirow{3}{*}{$\frac{\frac{\text { Oxidations }}{\mathrm{Fe}(\mathrm{III}) \mathrm{Fe}(\mathrm{N})}}{\mathrm{E}_{1 / 2^{\mathrm{b}}}}$} & \multicolumn{2}{|l|}{ Rectuctions } & \multirow[t]{3}{*}{ Ref. } \\
\hline & & & $\mathrm{Fe}(\mathrm{III}) \mathrm{Fe}(\mathrm{II})$ & $\mathrm{Fe}(\mathrm{II}) \mathrm{Fe}(\mathrm{I})$ & \\
\hline & & & $\mathrm{E}_{1 / 2}$ & $\mathrm{E}_{1 / 2}$ & \\
\hline$\left[\mathrm{Fe}^{\mathrm{II}}(\mathrm{TPP})(4-\mathrm{CNpy})_{2}\right]^{+C \mathrm{~d} / n}$ & - & - & 034 & - & [32] \\
\hline$\left[\mathrm{Fe}^{\mathrm{N}}(\mathrm{TPPX} \text { 1-NMelm })_{2}\right]^{+t}$ & - & - & -0089 & - & [32] \\
\hline$\left[\mathrm{Fe}^{2}\{(\mathrm{TPP})(2-6)\}(\mathrm{py})_{2}\right]^{+8}$ & - & - & 035 & - & {$[32]$} \\
\hline 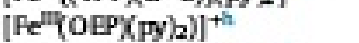 & - & - & -0.16 & - & [33] \\
\hline$\left.\left[\mathrm{Fe}^{\mathrm{J}}\left(\mathrm{OEP} \mathrm{XNO}_{\mathrm{N}} \mathrm{im}\right)_{2}\right)\right]^{+1}$ & - & - & -039 & - & [33] \\
\hline 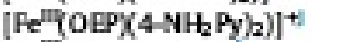 & & - & -039 & - & [33] \\
\hline$\left[\mathrm{Fe}^{\mathrm{II}}\left(\mathrm{OEPX}(\mathrm{pyz})_{2}\right)\right]^{+2}$ & 159 & 123 & -020 & - & [31] \\
\hline 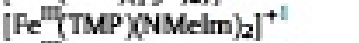 & - & - & -0.27 & - & [32] \\
\hline$\left[\mathrm{Fe}^{\mathrm{II}}(\mathrm{TMP})(1-\mathrm{Melm})_{2}\right]^{+}$ & - & - & -0.27 & - & [32] \\
\hline$\left[\mathrm{Fe}^{\mathrm{NI}}(\mathrm{TMPX} \text { X2-Melm) }]_{2}\right]^{+m}$ & - & - & -0.21 & - & [32] \\
\hline$\left[\mathrm{Fe}^{\mathrm{J}}\left(\mathrm{TClPPPX} \mathrm{PhEtNH}_{2} \mathrm{~h}_{2}\right](\mathrm{I})\right.$ & 1.60 & 111 & -038 & -1.23 & this wark \\
\hline
\end{tabular}

"The potentials are reported versus $S C D$

${ }^{b} \mathrm{E}_{1 / 2}$ - half-wave potential.

c TPP - meso-tetraphenylparphyr inato

d In DMP salvent.

- 4-CNpy - 4-cymopyridine.

'1-MeHlm - 1-methylimidazale.

8 [(TPPX 2-GF) $\}-m e s o-t e t r a k i s(2,6-d i f l u a r o p h e n y l) p o r p h y r i n a t o$

h OEP - actaethylporphyrinats.

' NMeHlm - N-methylimidazale.

4-NHPy - 4-aminopyridine)

pyz - pyrazine.

1 TMP - meso-tetramesitylparhyrimata.

2-MeHlm - 2-methylimidazale. 


\section{Conclusion}

The synthesis, the molecular structure, the magnetic the UV-visible, the IR and the cyclic voltammetry data of a new hexacoordinated ferric complex bearing $\mathrm{N}$-donor axial ligand with an alpha aryl carbon of an amino group (I) is reported herein using the meso-tetra(para-chlorophenyl)porphyrin. This is the first example of a hexa-coordinated amino iron(III) porphyrin complex because the reaction of a primary amine with an iron(III) metalloporphyrin leads to the autoreduction of the center metal and a hexacoordinated iron(II) porphyrin species is formed. The magnetic data are appropriate of a low-spin $(S=1 / 2)$ iron(III) metalloporphyrin which is confirmed by the value of the average equatorial distance ( $\mathrm{Fe}-\mathrm{Np}$ ) between the central metal and the nitrogen atoms of the porphyrinato ligand. The interactions between the hydrogens of the phenyl group of the trans two 4-ethylaniline axial ligands and the $\mathrm{N}$ atoms of the pyrrole of the TCPP moiety are weak compared to the bis(substituted pyridine) iron(III) metallporphyrins leading to a planar porphyrin core with a nearly eclipsed $\mathrm{H}$ protons of the 4-ethylaniline ligands and the closest $\mathrm{Fe}-\mathrm{Np}$ vectors. The planarity of the porphyrin macrocycle is also related to the shift of the $\mathrm{E}_{1 / 2}$ [Fe(III)/Fe(II)] of complex (I) toward more negative value. The crystal packing of our iron(III) bis (4ethyaniline) species is made by a three-dimensional supramolecular structure stabilized by $\mathrm{N}-\mathrm{H} \cdots \mathrm{O}$ and $\mathrm{O}-\mathrm{H} \cdots \mathrm{O}$ hydrogen bonds as well as the non-comventional $\mathrm{C}-\mathrm{H} \cdots \mathrm{O}$ and $\mathrm{C}-\mathrm{H} \cdots \mathrm{Cg}$ intermolecular interactions where $\mathrm{Cg}$ is the centroid of a phenyl ring of the 4-ethyaniline axial ligand.

\section{Acknowledgements}

The authors gratefully acknowledge financial support from the Ministry of Higher Education and Scientific Research of Tunisia.

\section{Appendix A. Supplementary data}

Supplementary data related to this article can be found at https://doi.org/10.1016/j.molstruc.2017.10.023.

\section{References}

[1] CJ. Epstzin, D.K. Strauh, C Maricandi, Mösshuer spectra of some porphyrin complexes with pyridine, piperidine, and imidazole, Inorg. Chem. 6 (1967) $1720-1724$

[2] DJ. Caudio, C.N. La Mar, The band structure of the tetracyanoplatimate chain, J. Am Chem. Soc, 100 (1978) 1112-1119.

[3] CE. Castra, M. Jamin, W. Yolooyama, R.J. Wade, Ligation and reduction of ir an(III) porphyrins by amines. A model for cytochrome $\mathrm{P}-450$ monoamine axidze, Am Chem. Soc. 108 (1989) 4179-4187.

[4] O.Q. Murra, P.S. Madlal, R.A.P. Warby, T.B. Sedn, C. Hearne, Structural, conformational, and spectroscopic studies of primary amine complexes of iran(II) parplyrins, Inorg. Chem. 38 (1999) 4724-4736.

[5] S. Dhifaoui, W. Harhouri, A. Bujacr, H Nasri, Crystal structure of bia'benzylamine) $[5,10,15,20$-tetrakid 4-chlarophenyl)porphyrinato iron(II) $\mathrm{n}$-hesane monosalvite, Acta Cryst. E72 (2016) 102-105.

[6] L. B. Hassen, K. Ezzayani, Y. Rousselin, C Stern, H. Nasri, CE. Schulz, Syntheris UV/vis, FT= IR and Mössbauer spectroscopic characterization and molecular structure of the Bisi 4-(2-aminoetlyl knorpholine](tetrakis'4-metbxyphenyl) porphyrimto) iron(II) camplex, J. Mol. Struct. 1110 (2016) 138-142.

[7] P.J. Marsh, J. Silver, M.CR. Symons, P.A. Taiwo, Mössbauer and electron paramagnetic resanance studies on some new bis-(ligated) porphyrimto ir an(III) complexes with aliphaticamines. Models for cytochromes b. I Chem. Soc. Dalton Trars. (1996) 2361-2369.

[8] E.S. Schmidt, TS. Galderwood, T.C. Aruice, Synthes is and characterization of a meso-tetrakis 4- ferrocenylpherryl porphyrin and examination of its ability to undergo intramolecular photocitaly zed electron trarsfer, lnarg. Chem 25 (1986) 3718-6103.

[9] C. Morice, PL Maux, C. Simoneaux, Synthes is and characterization of low. spin bis(amino ester) iron(III) porphyrin complexer, lnarg. Chem. 37 (1998)

\section{$6100-6103$}

[10] M. Kobeissi, L. Oupeth, C. Simonneaux, Synthesis and characterization of low. spin bis(amino ester) iran(III) parphyrin compleser, Acta Cryst. CS8 (2002) m443.

[11] S.E Martinez, D. Huang A Szcrepaniak, W.A. Craner, IL. Smith, Crystal structure of chloroplast cytachrome freveals a novel cytochrome fold and unexpected heme ligation, Structure 2 (1994) 95-105.

[12] A.D. Adler, P.R. Lango, ID. Finarelli, I Coldmacher, I Assour, L.A. Karsalooff, A simplified synthesis for meso-tetraphenylparphine, J. Org. Chem. 32 (1967), $476-476$

[13] JP. Collman, R.R. Gagne, C, Reed, T.R. Halbert, C. Lang. W.T, Robinsan, Pidket fence porplyri irs. Synthetic models for wygen binding hemoproteirs, I Am. Chem Soc 97 (1975) 1427-1439.

[14] A Cismelseed, E. Bominaar, E, Bill, AX. Trautwein, H. Wirkkler, H. Nasri, P. Doppelt, D. Mandon, I Fischer, R. Weiss, Sio-coordinate quantummechanically weakley spin-mixed (S - 5/2, 3/2) (triflato)aquoiron(III) "picket-fence" por phyrin complex; synthesis and structural, Moess bauer, EPR, and magnetic characterization, Inorg. Chem. 92 (1990) 2741-27.99.

[15] Barnshaw, Introduction to Magnebchemistry. Academic Press, London, 1908.

16] R.H. Blessing ActaCryst. A 51 (1995) 33.

[17] A. Altomare, C. Casacarano, C. Ciaconazza, A Cuagliardi, M.C. Burb, C. Polidari, M.J Camalli, Irsights on the uvfvis, fluarescence, and cyclic voltammetry proper ties and the molecular structures of $\mathrm{Zn}$ ll tetraphenylporphyrin compleves with pseudohalide axial azido, cyanato- $\mathrm{N}$ thiocyanab- $\mathrm{N}$, and cyanido ligands, Appl. Crystal logrr. 27 (1994) 435-436.

[18] C.M. Sheldrick, Acta Cryst. C71 (2015) 3 .

[19] W.R. Scheidt, C.A. Reed, Spin-statejstereochemical relationships in ir an porphyrirs; implications for the hernoproteirs, Chem. Rev. 81 (1981) 543-555.

[20] M.E Kastner, W.R. Scheidt, T, Mashiloo, C,A. Reed, Molecular structure of diaqua alpha, beta, gamma delta tetrapherrylporphinatoiron(III) perchlarateandperchlorab-alpha, beta, gamma,delta tetraphenylporphimtoiron(III). Two new structural types for iron(III) porphyrins, I Am. Chem. Soc. $100(1978) 666-667$.

[21] M.K. Sta, C.P. Cupta, F, A.Walloer, W.R. Scheidt, Models of the cytochromes b. Control of axial ligand orientation with a hindered porphyrin system, I Am. Chem. Soc, 113 (1991) $5707-5714$

[22] W.R. Scheidt, Y.J Lee, Preparation and molecular stereochemistry of arionic difluaro (meso-tetraphenylparphünato)iron(III), a high-spin six-coardinat: iron(III) porphyrinate with an unusully expanded core and a lrydrogenbonded "distal" imidnzole, I. Am. Chem. Soc. 105 (1983) 778-782

[23] M. Mylrajan, LA. Andersson, I Sun, T.M. loehr, CA. Thamas, E.P. Sullivan, M.A. Thomson, KM. Lang O.P. Anderson, Resomance raman spectroscopic core-siz correlations for the crystallogra phically defined carnplexes

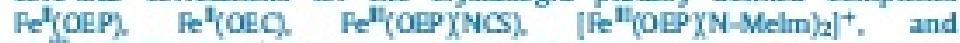

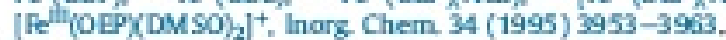

[24] R. Quinn, CE, Strouse, JS. Valentine, Crystal structure and properties of a potasium cryptate salt of bis(4-methylimidazolato)(telrapherryl por phinito) iron(III) lnarg. Chem. 22 (1983) $2934-2940$.

[25] D. Imiss, S.M. Solfis, CI. Strouse, The electranic structure of highly arisotropic low-spin ferric porphyrin carnplexes based on single-crystal EPR measurements, I Am. Chem. Soc 110 (1988) 5644-5650.

[26] M.K. Safo, F.A. Walker, A.M. Raitsimning. W.P. Walters, D.P. Dolata, P.C. Debrunner, WR Scheidt, Axial ligand orientation in iran(III) porphyrinates; effect of axial $\pi$-axceptors. Characterization of the low-spin complex [Fe(TPPX 4-CNPy) 2 ]CO4 ]. Am. Chem. Soc, 116 (1994) 7754-7700.

[27] W.R. Scheidt, D.K. Ceiger, K.]. Hayes, Control of spin state in (porphinatb) iron(III) complexes. An axial ligand orientation effect leading to an intermediate-spin complex. Molecular structure and physical character iration of the manoclinic form of bis(3-chlaropyridine)(octaethyl porphinatb)iron(III) perchlarate, J. Am Chem. Soc. 104 (1982) 7767-7770.

[28] M.K. S.fa, C.P. Cupta, F.A. Walker, W.R. Scheidt, Models of the cytochromes b. Control of axial ligand arientation with a hindered porphyrin system, I Am. Chem Soc 113 (1991) $5497-5510$

[29] S.P. Rith, M.M. Olmstend, A.L. Bakch, Electron distribution in iron octaetlylaxophlorin compleses. Importance of the Pe(III) woophlarin triarion form in the bis-pyridine and bis-imidzzole camplexes, lnarg. Chem. 45 (2006) $6083-6093$.

[30] K.M. Kadish, A. A. P. Lever, H.B. Gray, Iron Parplryrin, Part 2, Chap. 4 AddisonWesley Publishing Compary, Massachusetts, 1983.

[31] M.K. Motlagh, M. Naroozifar, I Saffari, B. . Patrick, Models of the cytochrames redox properfies and jacobson thermodynamic stabilifies of complexes of "hindered" iron(III) and iron(II) tetrapherrylporphyrinates with substituted pyridines and imidazoles, lnarg. Chim. Acta 362 (2009) 4721-4728.

[32] M.JM. Nesset, N.V.Shokhirev, PD. Enemark, SE, Ann, F. Walloer, Models of the cybchromes, Redox properties and ther modymic stabilities of camplexes of "hindered" iron(III) and ir on(II) tetraphernylporphyrimtes with substituted pyridines and imidazoles, lnarg. Chem. 35 (1996) $5188-5200$.

[33] K.M. Kadish, C.H. Su, Relationships between electron-trars fer ratecanstants of bis (ligated) Yoctaethyl por phinato Yron(III) perchlorate and the presence of a spin equilibria, I Am. Chem. Soc. 105 (1983) 177-18a. 